\title{
ANALISIS PENGARUH ANGKA BEBAN KETERGANTUNGAN, KEPADATAN PENDUDUK, GARIS KEMISKINAN TERHADAP INDEKS GINI DI INDONESIA
}

\author{
Rahayu Budi Utami \\ Departemen Biostatistika dan Kependudukan, Fakultas Kesehatan Masyarakat \\ Universitas Airlangga Surabaya \\ Email: rarahayu25@yahoo.com
}

\begin{abstract}
The purpose of this study was to analyze and determine the effect of the number of dependencies, population density, and poverty lines on the Gini index in Indonesia. This study uses secondary data from Indonesia's health profile in 2016 with an analysis method using Ordinary Least Square (OLS) statistical tests or called multiple linear regression. The results of the analysis showed that the dependency load number has an influence on the Gini index with a significant value of 0.038, population density affects the Gini index with a significant value of 0.017, and the poverty line affects the Gini index with a significant value of 0.000 .
\end{abstract}

Keywords: Dependency Ratio, Gini Index, Population Destiny and Poverty Line

\begin{abstract}
ABSTRAK
Tujuan dalam penelitian ini adalah untuk menganalisis dan mengetahui pengaruh angka beban ketergantungan, kepadatan penduduk, dan garis kemiskinan terhadap indeks gini di Indonesia. Penelitian ini menggunakan data sekunder dari profil kesehatan Indonesia tahun 2016 dengan metode analisis menggunakan uji statistik Ordinary Least square (OLS) atau disebut regresi linier berganda. Hasil uji analisis didapatkan hasil bahwa angka beban ketergantungan memiliki pengaruh terhadap indeks gini dengan nilai sign sebesar 0,038 , kepadatan penduduk berpengaruh terhadap indeks gini dengan nilai sign sebesar 0,017, dan garis kemiskinan berpengaruh terhadap indeks gini dengan nilai sign sebesar 0,000 .
\end{abstract}

Kata kunci: Indeks Gini, Angka Beban Ketergantungan, Kepadatan Penduduk dan Garis Kemiskinan

\section{PENDAHULUAN}

Indeks gini merupakan koefisien yang menunjukkan suatu tingkatan ketimpangan atau kemerataan dari suatu pendapatan. Jika indeks gini menunjukkan nilai 0 maka menunjukkan distribusi yang merata dan jika nilai indeks gini 1 maka menunjukkan distribusi yang timpang ${ }^{1}$. Oshima menetapkan kriteria tingkat distribusi pendapatan suatu masyarakat sebagai berikut: a) Kaetimpangan taraf rendah, bila $\mathrm{G}<0,35, \mathrm{~b}$ ) Ketimpangan taraf sedang, bila G antara 0,35$0,5, \mathrm{c})$ Ketimpangan taraf tinggi, bila $\mathrm{G}>0,5^{2}$. Ketimpangan atau kemerataan pendapatan disuatu negara menyebabkan perubahan struktur ekonomi dan sering menyebabkan suatu 
perubahan kesejahteraan di suatu negara. Di Indonesia, periode 2007-2010, ketimpangan distribusi pendapatan lebih tinggi dibanding periode sebelumnya. Meski kemiskinan mengalami penurunan tetapi pertumbuhan pendapatan pada penduduk golongan bawah lebih rendah (2\%/tahun) dibandingkan tingkat pertumbuhan pendapatan penduduk golongan atas mengalami pertum-buhan sebesar $6 \%$ per tahun $^{3}$. Pemerintah Indonesia menggunakan capaian ratio gini sebagai salah satu target APBN. Tingkat ketimpangan ekonomi antar penduduk di Indonesia sampai dengan Desember 2015 sudah turun ke angka 0,408 dari angka 0,413 dari data terakhir di tahun 2014, angka ini sesuai dengan target di $\mathrm{APBN}^{4}$.

Hasil perbandingan antara penduduk yang memiliki usia produktif dengan penduduk yang memiliki usia tidak produktif merupakan rasio ketergantungan atau bisa disebut dengan angka beban ketergantungan ${ }^{5}$. Rasio ketergantungan dapat digunakan sebagai indikator kasar yang menunjukkan keadaan ekonomi suatu negara, bila angka ketergantungan besar maka beban tanggungan suatu negara juga semakin besar. Di Indonesia struktur usia penduduk mayoritasi dominasi oleh penduduk yang memiliki usia produktif, berdasarkan hasil sementara proyeksi penduduk pada 2010-2035 sampai dengan 66,80 persen pada tahun 2012 lalu meningkat pada tahun 2013 menjadi 67,00 persen. Disamping itu untuk komposisi penduduk berumur 0-14 tahun bisa dikatakan cukup tinggi meskipun berangsur menurun dari 28,10 persen pada tahun 2012 menjadi 27,80 persen pada tahun 2013 .

Tabel 1. Komposisi Penduduk (\%) dan Angka Beban Ketergantungan, 2010-2013

\begin{tabular}{ccccc}
\hline Tahun & 0-14 Tahun & 15-64 Tahun & 65 Tahun + & $\begin{array}{c}\text { Angka Beban } \\
\text { Ketergantungan } \\
\text { (jiwa) }\end{array}$ \\
\hline (1) & (2) & $(3)$ & (4) & (5) \\
\hline 2010 & 28,60 & 66,50 & 5,00 & 50,48 \\
2011 & 28,30 & 66,60 & 5,00 & 50,06 \\
2012 & 28,10 & 66,80 & 5,10 & 49,64 \\
2013 & 27,80 & 67,00 & 5,20 & 49,25 \\
\hline Sumber : Hasi Sementara Proyeksi Penduduk 2010-2035
\end{tabular}

Perubahan struktur penduduk dapat ekonomi, dimana masing-masing individu berpengaruh terhadap besarnya angka beban pendapatan dan pengeluaran di dalam suatu ketergantungan. Pertambahan penduduk yang keluarga itu berbeda. Di dalam negara maju sangat tinggi menimbulkan berbagai masalah pertumbuhan ekonomi dapat meningkatkan kependudukan termasuk masalah pada sektor pertumbuhan ekonomi karena didukung dengan 
teknologi dan sumber daya manusia yang berkualitas. Tetapi di dalam negara berkembang dampak pertumbuhan ekonomi terhadap pembangunan tidaklah seperti yang diharapkan, karena kondisi di negara berkembang penggunaan teknologi masih sederhana, sember daya manusia masih kurang tenaga ahli. Berbagai masalah yang disebabkan oleh kepadatan penduduk dapat mempengaruhi ekonomi yang dapat menciptakan suatu ketimbangan pendapatan. Jumlah penduduk berpengaruh signifikan terhadap pertumbuhan ekonomi ${ }^{6}$.

Garis Kemiskinan merupakan suatu batas nilai tukar rupiah dengan kemampuan daya beli minimal ${ }^{7}$. Garis kemiskiman mempengaruhi besar kecilnya jumlah penduduk miskin karena memiliki pengeluaran per kapita per bulan ratarata di bawah garis kemiskinan. Garis kemiskinan memiliki dua komponen yaitu: Garis Kemiskinan Makanan (GKM) dan Garis Kemiskinan bukan-Makanan (GKBM).

Tabel 2. Garis kemiskinan, jumlah dan persentase penduduk miskin menutut daerah, Maret 2006-Maret 2007

\begin{tabular}{|c|c|c|c|c|c|}
\hline \multirow{2}{*}{ Daerah/Tahun } & \multicolumn{3}{|c|}{ Garis Kemiskinan (Rp/Kapita/Bln) } & \multirow{2}{*}{$\begin{array}{c}\text { Jumlah } \\
\text { penduduk } \\
\text { miskin (juta) }\end{array}$} & \multirow{2}{*}{$\begin{array}{c}\text { Persentase } \\
\text { penduduk } \\
\text { miskin }\end{array}$} \\
\hline & Makanan & Bukan Makanan & Total & & \\
\hline (1) & (2) & (3) & (4) & (5) & (6) \\
\hline \multicolumn{6}{|l|}{ Perkotaan } \\
\hline Maret 2006 & 126.163 & 48.127 & 174.290 & 14,49 & 13,47 \\
\hline Maret 2007 & 132.258 & 55.683 & 187.942 & 13,56 & 12,52 \\
\hline \multicolumn{6}{|l|}{ Perdesaan } \\
\hline Maret 2006 & 102.907 & 27.677 & 130.584 & 24,81 & 21,81 \\
\hline Maret 2007 & 116.265 & 30.572 & 146.837 & 23,61 & 20,37 \\
\hline \multicolumn{6}{|l|}{ Kota+Desa } \\
\hline Maret 2006 & 114.125 & 37.872 & 151.997 & 39,30 & 17,75 \\
\hline Maret 2007 & 123.992 & 42.704 & 166.697 & 37,17 & 16,58 \\
\hline
\end{tabular}

Sumber: Diolah dari data Susenas Panel Maret 2006 dan Maret 2007

Selama periode Bulan Maret 2006-2007

Garis Kemiskinan naik sebesar 9,67 persen, yaitu dari Rp. 151.997 per kapita per bulan pada Bulan Maret 2006 menjadi Rp. 166.697 per kapita per bulan pada Bulan Maret 2007. Pada Bulan Maret 2006, sumbangan GKM terhadap GK sebesar 75,08 persen, tetapi pada bulan Maret 2007 turun menjadi 74,38 persen.
Regresi merupakan alat statistika yang berfungsi untuk melihat adanya hubungan antara variabel independen dengan variabel dependen. Metode regresi digunakan untuk mengetahui model terbaik yang dapat menggambarkan hubungan antara variabel independen dengan variabel dependen. Terdapat 2 macam regresi, yaitu regresi linier dan regresi non linier. Salah 
satu macam dari regresi linear adalah regresi linear berganda yang artinya variabel dependent dipengaruhi oleh dua atau lebih variabel independent.

Ada beberapa asumsi dalam analisis regresi linier, diantaranya: data y memiliki skala minimal interval, data $\mathrm{x}$ memiliki skala minimal nominal (jika data $\mathrm{x}$ berskala nominal/ordinal harus dengan variabel dummy), Linieritas, Tidak saling multikolinieitas antar variabel independent, Homoscedascity. Error berdistribusi normal, Error saling bebas.

Pada uji statistika dengan regresi linier berganda untuk variabel dependen harus memiliki skala data interval/ratio dan variabel independent dengan skala data interval/ratio. Oleh sebab itu pada penelitian ini menggunakan uji regresi linier berganda karena variabel dalam penelitian ini memiliki skala data interval/ratio yaitu indeks gini, angka beban ketergantungan, kepadatan penduduk, garis kemiskinan.

\section{METODE PENELITIAN}

Penelitian ini dilakukan selama 3 bulan. Populasi penelitian ini adalah provinsi di Indonesia sebanyak 34 Provinsi dengan menggunakan total samping. Data yang digunakan dalam penelitian ini adalah data sekunder yang diperoleh dari profil kesehatan Indonesia tahun 2016.

Pada penelitian ini merupakan jenis penelitian analitik, dengan menggunakan teknik penelitian bersifat cross sectional karena variabel diukur dalam satu periode waktu tertentu. Variabel yang diteliti terdiri atas variabel dependen dan variabel independen. Variabel dependen dalam penelitian ini adalah Indek Gini, sedangkan variabel independen dalam penelitian ini adalah angka beban ketergantungan, kepadatan penduduk dan garis kemiskinan.

Analisis data yang digunakan dalam penelitian ini adalah model regresi linear berganda sebagai berikut:

$$
Y_{\mathrm{i}}=\beta_{0}+\beta_{1} X_{1}+\beta_{2} X_{2}+\beta_{3} X_{3}+\varepsilon i
$$

Y $i$ adalah Indek Gini di Indonesia, X1 adalah Angka Beban Ketergantungan (jiwa), X2 adalah Kepadatan penduduk di Indonesia (juta jiwa), X3 adalah Garis Kemiskinan (Rp/Kapita/Bulan). $\beta 0$ adalah intercept atau konstanta, $\beta 1, \beta 2, \beta 3$ adalah koefisien regresi dan $\varepsilon$ i adalah eror.

Uji koefisien determinasi berfungsi untuk mengetahui besarnya persentase variabel dependen yang bisa dijelaskan oleh variabel independen dalam model. Nilai koefisien determinasi dapat digunakan untuk mengukur besarnya kontribusi dari variabel-variabel independen terhadap variabel dependen. Nilai koefisien determinasi berada pada rentan angka nol sampai satu. Semakin mendekati satu maka model dikatakan semakin baik karena berarti semakin tepat atau cocoknya suatu garis regresi serta makin besar variasi variabel independen dapat menjelaskan variasi variabel dependen. 
Uji F dilakukan untuk mengetahui apakah variabel bebas secara bersama-sama berpengaruh signifikan terhadap variabel terikat. Uji koefisien regresi secara parsial digunakan untuk melihat apakah tiap-tiap variabel independen memiliki pengaruh yang signifikan terhadap variabel dependen.

\section{HASIL DAN PEMBAHASAN}

Tabel 3. Uji Asusmsi Normalitas dengan OneSample Kolmogorov-Smirnov Test

\begin{tabular}{|ll|r|}
\hline & & Indeks Gini \\
\hline $\mathrm{N}$ & & 34 \\
Normal & Mean & .3597 \\
Parameters ${ }^{\mathrm{a}, \mathrm{b}}$ & Std. Deviation & .03746 \\
& Absolute & .115 \\
Most Extreme & Positive & .115 \\
Differences & Negative & -.085 \\
& .668 \\
Kolmogorov-Smirnov Z & .764 \\
Asymp. Sig. (2-tailed) &
\end{tabular}

Berdasarkan hasil uji statistic pada Tabel One-Sample Kolmogorov-Smirnov Test di atas didapatkan nilai (koefisien) adalah $0.764>(a)=$ 0,05, maka bisa disimpulkan bahwa Ho diterima artinya data berdistribusi normal.

Tabel 4. Uji Asumsi Autokorelasi

\begin{tabular}{|l|c|r|r|r|}
\hline Model & $\mathrm{R}$ & $\begin{array}{c}\mathrm{R} \\
\text { Square }\end{array}$ & $\begin{array}{c}\text { Adjusted } \\
\mathrm{R} \\
\text { Square }\end{array}$ & $\begin{array}{c}\text { Durbin } \\
- \\
\text { Watson }\end{array}$ \\
\hline 1 & $.737^{\mathrm{a}}$ & .544 & .498 & 1.821 \\
\hline
\end{tabular}

Berdasarkan Tabel Model Summary diatas diperoleh nilai DW adalah $1.821<2$, maka dapat disimpulkan bahwa tidak ada autokorelasi.

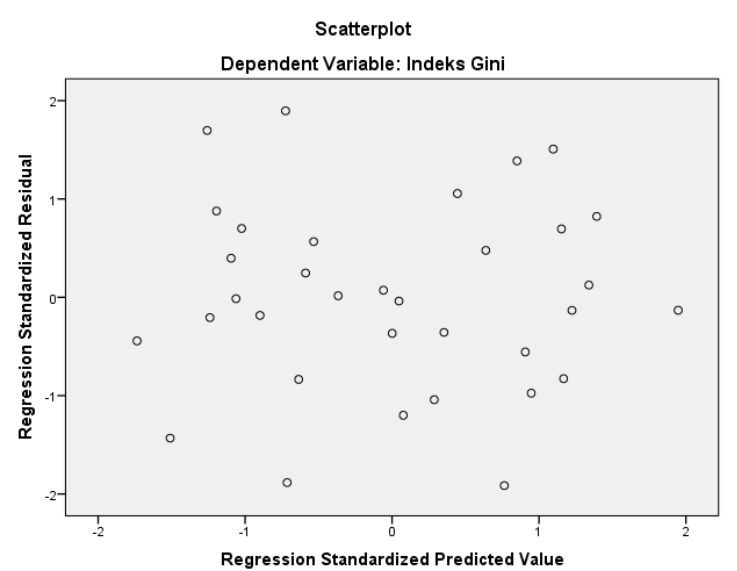

Gambar 1. Uji Asumsi Heteroskedastisitas

Dari gambar diatas menunjukkan tidak terjadi heteroskedastisitas karena sebaran plot tidak berpola.

Tabel 5. Uji Asumsi Multikolinieritas

\begin{tabular}{|c|c|c|c|c|}
\hline Model & $\mathrm{T}$ & Sig. & \multicolumn{2}{|c|}{$\begin{array}{l}\text { Collinearity } \\
\text { Statistics }\end{array}$} \\
\hline & & & $\begin{array}{c}\text { Tolera } \\
\text { nce }\end{array}$ & VIF \\
\hline (Constant) & 10.468 & .000 & & \\
\hline $\begin{array}{l}\text { Angka Beban } \\
\text { Ketergantun } \\
\text { gan }\end{array}$ & -2.174 & .038 & .847 & 1.180 \\
\hline $\begin{array}{l}\text { Kepadatan } \\
\text { Penduduk }\end{array}$ & 2.518 & .017 & .841 & 1.189 \\
\hline $\begin{array}{l}\text { Garis } \\
\text { Kemiskinan }\end{array}$ & -5.223 & .000 & .940 & .064 \\
\hline
\end{tabular}

Berdasarkan Tabel diatas diketahui bahwa dari hasil statistika menunjukkan bahwa ketiga variabel bebas memiliki nilai Tolerance $>0,1$ dan nilai VIF $<10$, maka dapat disimpulkan bahwa tidak terjadi multikolinieritas. 
Tabel 6. Hubungan Garis Kemiskinan, Angka beban Ketergantungan dan Kepadatan Penduduk terhadap Indek Gini

\begin{tabular}{lcc}
\hline \multicolumn{1}{c}{ Variabel } & $\mathrm{a}$ & Sign \\
\hline Angka Beban & 0,05 & 0,038 \\
Ketergantungan & & \\
Kepadatan Penduduk & 0,05 & 0,017 \\
Garis Kemiskinan & 0,05 & 0,000 \\
\hline
\end{tabular}

Berdasarkan hasil olah uji statistik dengan metode regresi logistik berganda pada menunjukkan bahwa nilai signifikan variabel angka beban ketergantungan sebesar 0,038 < 0,05 maka dari itu hipotesis diterima yang artinya bahwa variabel angka beban ketergantungan berpengaruh signifikan terhadap indeks gini.

Selanjutnya, variabel kepadatan penduduk diperolah nilai $0,017<0,05$ yang berarti bahwa hipotesis diterima atau bisa dikatakan variabel kepadatan penduduk memiliki pengaruh yang signifikan terhadap indeks gini. Variabel garis kemiskinan memperoleh nilai $0,000<0,05$, hipotesis diterima yang artinya bahwa variabel garis kemiskinan berpengaruh signifikan terhadap indeks gini.

\section{Pembahasan}

\section{Deskripsi Umum Ketimpangan Pendapatan di Indonesia}

Perkembangan Perekonomian di Indonesia pada tahun 2016 tercatat sebesar $5,2 \%$, angka ini membaik dibandingkan pada tahun 2015 yang hanya sebesar 4,88\% (BPS). Di Indonesia sejak tahun 1982 hingga saat ini
Indeks Gini digunakan sebagai indikator untuk mengukur ketimpangan pendapatan. Pada tahun 1982-1997 Indeks Gini Indonesia sebesar 0,2986 dengan angka tertinggi berada pada angka 0,31 dan terendah berada pada angka 0,29. Sedangkan pada tahun 1998 sampai dengan tahun 2013 Indeks Gini di Indonesia memiliki rata-rata sebesar 0,3397 dengan angka tertinggi adalah 0,413 dan angka terendah adalah 0,29.

Menurut sudut pandang ekonomi makro, perkembangan ekonomi adalah penambahan PDB yang bermakna sebagai penambahan pendapatan nasional ${ }^{8}$. Sebagaimana yang telah dijelaskan oleh World Bank tahun 2014, bahwa Indonesia mampu mendorong perekonomian agar mengalami pertumbuhan yang pada akhirnya mampu menekan kemiskinan, namun pertumbuhan ekonomi tersebut tidak bisa dirasakan oleh seluruh masyarakat. Dengan ketimpangan yang relative tinggi, ditakutkan pada periode 2004-1013 akan menjadi dekade yang hilang yang mana ketimpangan di Indonesia mengalami pertumbuhan yang samakin tinggi ${ }^{9}$. Pada tahun 2013 Indeks Gini di Indonesia bernilai 0,431 dimana angka ini bisa dikatakan sebagai ketimpangan pendapatan di Indonesia semakin buruk, seperti yang diketahui bahwa Indeks Gini bernilai 0 sampai 1, yang berarti semakin mendekai 1 maka ketimpangan pendapatan semakin memburuk.

Indeks gini di Indonesia pada tahun 2016 sebesar 0,39, angka ini menurun 0,02 persen 
dibandingkan tahun 2015 sebesar 0,41 yang berarti bahwa ketimpangan pendapatan di Indonesia tahun 2016 semakin membaik karena angka koefisien Indeks Gini mendekati angka 0.

Faktor-faktor yang Mempengaruhi Indeks Gini di Indonesia

\section{Angka Beban Ketergantungan}

Angka beban ketergantungan Angka beban ketergantungan memiliki pengaruh terhadap indeks gini karena memiliki nilai signifikan sebesar $0,038<0,05$. Angka beban ketergantungan merupakan perbandingan antara penduduk usia produktif dan usia tidak produktif. Usia produktif merupakan kelompok usia penduduk antara 15-64 tahun atau bisa juga dikatakan sebagai angkatan kerja yang mampu mendapatkan penghasilan untuk memenuhi segala kebutuhan hidupnya, sedangkan penduduk usia tidak produktif adalah kelompok penduduk pada usia 0-14 tahun dan penduduk pada usia 65 tahun keatas atau bisa disebut juga dengan bukan angkatan kerja yang berarti pada penduduk usia ini tidak bisa memperoleh penghasilan untuk mencukupi kebutuhan hidupnya.

Semakin tinggi rasio ketergantungan maka artinya bahwa makin tinggi beban yang ditanggung oleh penduduk yang tidak produktif, sementara itu bila rasio ketergantungan makin rendah, maka makin rendah beban yang ditanggung usia produktif untuk menompang biaya penduduk yang memiliki usia tidak produktif.
Angka beban ketergantungan ini bisa mempengaruhi ketimpangan pendapatan di suatu negara karena ketidakstabilan antara pendapatan yang diperoleh dengan biaya pengeluaran untuk menanggung biaya hidup usia produktif dan tidak produktif guna mencukupi kebutuhan sehari-hari.

Menurut penelitian yang dilakukan oleh Rusli Abdullah mengenai faktor yang memepengaruhi ketimpangan pendapatan di Jawa tengah dengan menggunakan data panel dari tahun 2002-2012 diperoleh hasil signifikan pada variabel share output perekonomian yang diterima pengusaha dan upah, sedangkan variabel urbanisasi dan dependensi rasio memperoleh hasil tidak signifikan ${ }^{10}$. Tetapi pada penelitian yang menggunakan data dari profil kesehatan di Indonesia pada tahun 2016 diperoleh hasil bahwa variabel angka beban ketergantungan berpengaruh signifikan terhadap Indeks Gini dengan nilai $p$ value sebesar 0,017.

\section{Kepadatan Penduduk}

Penduduk adalah unit utama dalam pembangunan di suatu negara,akan tetapi di sisi lain penduduk bisa menjadi suatu beban bagi negara untuk mebangun pertumbuhan ekonomi. Laju pertumbuhan penduduk yang tinggi dapat menyebabkan kesenjangan di dalam masyarakat.

Kepadatan penduduk disuatu negara akan memberikan dampak pada peningkatan kualitas hidup masyarakat dan dapat menghambat upaya peningkatan kemakmuran suatu negara. 
Ketidakseimbangan antara pendapatan penduduk yang tinggi mengakibatkan penduduk yang relative kecil dan juga kepadatan pendapatan per kapita di suatu negara itu rendah.

Tabel 7. Persentase penduduk di Pulau di Jawa dan Kepadatan Penduduk Menurut Pulau, Tahun 2010-2013

\begin{tabular}{cccccccc}
\hline & \multirow{6}{*}{$\begin{array}{c}\left.\text { Kepadatan Penduduk (jiwa } / \mathrm{km}^{2}\right) \\
\text { Tahun }\end{array}$} & $\begin{array}{c}\text { Penduduk } \\
\text { di Pulau } \\
\text { Jawa }\end{array}$ & Sumatera & Jawa $\begin{array}{c}\text { Bali \& } \\
\text { Nusa } \\
\text { Tenggara }\end{array}$ & Kalimantan & Sulawesi & $\begin{array}{c}\text { Maluku } \\
\text { dan Papua }\end{array}$ \\
\cline { 3 - 9 } & $(\mathbf{1})$ & $(\mathbf{2})$ & $(\mathbf{4})$ & $\mathbf{( 5 )}$ & $\mathbf{( 6 )}$ & $(7)$ & $(8)$ \\
\hline 2010 & 57,45 & 106 & 1059 & 180 & 25 & 92 & 13 \\
2011 & 57,32 & 108 & 1072 & 182 & 26 & 94 & 13 \\
2012 & 57,19 & 110 & 1084 & 185 & 27 & 95 & 13 \\
2013 & 57,06 & 111 & 1097 & 188 & 27 & 97 & 13 \\
\hline
\end{tabular}

Sumber : Hasil Sementara Proyeksi Penduduk 2010-2035

Hasil sementara proyeksi penduduk pada tahun 2010 sampai dengan tahun 2035, pada tahun 2013 persentase kepadatan penduduk di Pulau Jawa sebesar 57,06 persen dari total penduduk Indonesia. Pada tahun 2013 kepadatan penduduk di seluruh provinsi di Indonesia meningkat dari tahun sebelumnya sejalan dengan meningkatnya jumlah penduduk di tiaptiap provinsi.

Berdasarkan data proyeksi penduduk dari tahun 2010-2013 dapat dilihat bahwa setiap tahun jumlah penduduk mengalami peningkatan. Apabila peningkatan jumlah penduduk tidak diimbangi dengan pendapatan yang tinggi hal ini bisa menyebabkan ketimpangan pendapatan di Indonesia akibat dari ketidakseimbangan antara tingkat pendapatan yang relative rendah sedangkan kepadatan populasi penduduk di Indonesia cenderung semakin meningkat dari tahun ke tahun.

Berdasarkan penelitian oleh Vredrich Bantika tentang faktor-faktor yang mempengaruhi ketimpangan distribusi pendapatan di Sulawesi Utara di dapatkan hasil bahwa faktor yang berpengaruh adalah jumlah penduduk $(p=$ $0.008)$ dan pertumbuhan ekonomi $(p=0.015)$.

\section{Garis Kemiskinan}

Kemiskinann merupakan suatu permasalahan dasar yang menjadi pusat perhatian pemerintah di setiap negara terutama bagi negara yang sedang berkembang, salah satunya yaitu di Negara Indonesia. Guna mengukur kemiskinan, BPS memakai konsep kemampuan memenuhi kebutuhan dasar (basic needs approach $)^{11}$. Melalui pendekatan ini, kemiskinan dilihat sebagai suatu ketidakmampuan dalam segi ekonomi untuk memenuhi 
kebutuhan dasar meliputi makanan dan bukan makanan yang bisa diukur dari segi pengeluaran. Hal ini juga bisa diartikan sebagai ketidakmampuan dari sisi ekonomi untuk memenuhi kebutuhan makanan maupun nonmakanan yang bersifat mendasar.

Penduduk miskin merupakan penduduk yang memiliki pengeluaran perkapita perbulan rata-rata di bawah Garis Kemiskinan ${ }^{11}$. Garis kemiskinan terdiri atas dua komponen yaitu Garis Kemiskinan Makanan (GKM) dan Garis Kemiskinan Nonmakanan (GKNM). Garis Kemiskinan Makanan (GKM) adalah total pengeluaran dari 52 jenis komoditi dasar makanan yang nyata dikonsumsi oleh penduduk yang kemudian disamaratakan dengan 2100 kilokalori perkapita perhari. Garis Kemiskinan Nonmakanan (GKNM) merupakan total nilai kebutuhan minimum dari berbagai macam komoditi nonmakanan terpilih yang meliputi perumahan, sandang, pendidikan, dan kesehatan. Nilai kebutuhan minimum per komoditi/subkelompok nonmakanan dihitung dengan menggunakan suatu rasio pengeluaran komoditi/subkelompok yang telah ada dalam data Susenas modul konsumsi. Rasio tersebut dikalkulasi dari hasil survei paket Komoditi Kebutuhan Dasar (SPKKD) tahun 2004.

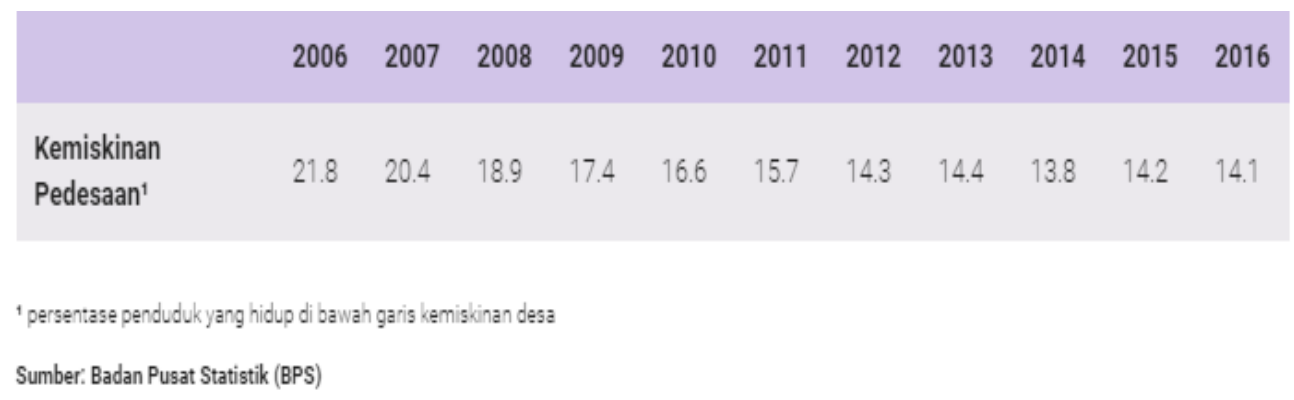

Gambar 2. Tabel Kemiskinan Pedesaan di Indonesia Tahun 2006 - 2016

Angka kemiskinan pedesaan di Indonesia memiliki persentase penduduk di pedesaan yang hidup di bawah garis kemiskinan desa tingkat nasional setelah tahun 2006, mengalami penurunan angka kemiskinan pedesaan yang cukup signifkan, dan angka kemiskinan pedesaan di Indonesia tahun 2016 sebesar 14.1.

\begin{tabular}{|cccccccccccc|} 
& 2006 & 2007 & 2008 & 2009 & 2010 & 2011 & 2012 & 2013 & 2014 & 2015 & 2016 \\
\hline Kemiskinan Kota $^{1}$ & 13.5 & 12.5 & 11.6 & 10.7 & 9.9 & 9.2 & 8.4 & 8.5 & 8.2 & 8.3 & 7.8 \\
\hline
\end{tabular}

'persentase pendudukyang hidup di bawah garis kemigkinan kota

Sumber: Badan Pusat Statistik (BPS)

Gambar 3. Tabel Kemiskinan Perkotaan di Indonesia Tahun 2006 - 2016 
Angka kemiskinan kota merupakan persentase penduduk di perkotaan yang tinggal di bawah garis kemiskinan kota tingkat nasional, Tabel diatas menunjukkan bahwa tingkat kemiskinan perkotaan berkurang mulai tahun 2006, dan pada tahun 2015 angka kemiskinan perkotaan di Indonesia sebesar 7.8.

Masalah ketimpangan pendapatan telah lama menjadi persoalan pertumbuhan ekonomi yang dialami oleh sejumlah negara yang sedang berkembang atau negara miskin. Negara berkembang memiliki tingkat pertumbuhan ekonomi yang tinggi pada tahun 1960-an dan mulai menyadari tentang pertumbuhan ekonomi yang memiliki sedikit manfaat dalam memecahkan masalah kemiskinan ${ }^{3}$. Masalah besar yang umum di alami negara berkembang seperti atas juga dialami oleh negara Indonesia yaitu ketimpangan distribusi pendapatan atau kesenjangan ekonomi dan tingkat kemiskinan atau banyaknya orang yang berada di bawah garis kemiskinan (poverty line).

\section{Analisis Model Regresi}

Faktor yang mempengaruhui indeks gini di Indonesia memakai data pada tahun 2016. Nilai koefisien tersebut merupakan variabel indeks gini yang akan dimasukkan kedalam model sehingga persamaannya berubah menjadi:

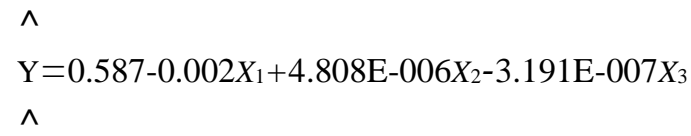

$\mathrm{Y}$ adalah indeks gini di Indonesia, $\mathrm{X}_{1}$ adalah angka beban ketergantungan, $X_{2}$ adalah kepadatan penduduk, $\mathrm{X}_{3}$ adalah garis kemiskinan. Hasil Uji statistic menunjukkan koefisien determinasi $\left(\mathrm{R}^{2}\right)$ dari model regresi adalah $0.544 \%$ artinya variabel angka beban ketergantungan, kepadatan penduduk, garis kemiskinan dapat menjelaskan indeks gini di Indonesia sebesar 54,4 \% dan sisanya sebesar 45,6\% dijelaskan oleh variabel lain yang tidak diteliti (tidak masuk kedalam model).

Pengaruh variabel angka beban ketergantugan, kepadatan penduduk dan garis kemiskinan terhadap indeks gini secara serentak memperoleh hasil pengujian nilai signifikan $\mathrm{F}$ sebesar 0.000 , sehingga signifikan $a>0,000$ menunjukkan bahwa diantara variabel angka beban ketergantungan, kepadatan penduduk dan garis kemiskinan terdapat minimal satu variabel yang berpengaruh signifikan terhadap indeks gini.

$\begin{array}{cccc}\text { Hasil uji } & \text { statistik } & \text { secara } & \text { parsial } \\ \text { menunjukkan } & \text { variabel angka } & \text { beban }\end{array}$ ketergantungan memperoleh nilai signifikan sebesar $0.038<a$ yang berarti angka beban ketergantungan memberikan pengaruh nyata terhadap indeks gini di Indonesia. Variabel kepadatan penduduk memiliki nilai signifikan sebesar $0.017<\mathrm{a}$ yang berarti kepadatan penduduk memberikan pengaruh nyata terhadap indeks gini di Indonesia. Dan variabel garis kemiskinan memiliki nilai signifikan sebesar 
$0.000<\mathrm{a}$, yang berarti garis kemiskinan memberikan pengaruh nyata terhadap indeks gini di Indonesia.

\section{SIMPULAN DAN SARAN}

\section{Simpulan}

Hasil penelitian ini menggunakan teknik analisis dengan uji statistik regresi linier berganda diperoleh hasil bahwa angka beban ketergantungan dengan nilai signifikan sebesar 0,038 berpengaruh terhadap Indeks Gini di Indonesia. Kepadatan penduduk dengan nilai signifikan sebesar 0,017 berpengaruh terhadap Indeks Gini di Indonesia. Garis kemiskinan dengan nilai signifikan sebesar 0,000 berpengaruh terhadap indeks gini di Indonesia.

\section{Saran}

Hasil penelitian ini bisa dijadikan dasar bagi penelitian lain dan bisa diperbarui dan lebih sempurna untuk literature pengetahuan di bidang statistika dan kependudukan.

\section{REFERENSI}

1. Kemenkes RI. Profil Kesehatan Indonesia 2016. Keputusan Menteri kesehatan Republik Indonesia. Jakarta. 2017.

2. BPS. Pemerataan Pendapatan dan Pola Konsumsi Penduduk Jawa Tengah 2003. Semarang: BPS Provinsi Jawa Tengah. 2003.

3. Kemenpan RI. Peraturan Menteri Pendayagunaan Aparatur Negara Dan Reformasi Birokrasi Republik Indonesia Nomor 35 Tahun 2012 Tentang Pedoman Penyusunan Standar Operasional Prosedur Administrasi Pemerintahan. Jakarta: Kemenpan RI. 2012.
4. http://www.aktual.com/bappenas-rasio-ginidesember-2015-turun-ke-0408.

5. BPS. Indikator Kesejahteraan Rakyat. Indonesia. 2013.

6. Novi, N.A. Analisis Pengaruh Investasi, Jumlah Penduduk dan Tenaga Kerja Terhadap Pertumbuhan Ekonomi di Indonesia Tahun 1999-2014. Universitas Muhammadiyah Surakarta. 2017.

7. Widjajanti, I. Penetapan Kriteria dan Variabel Pendataan Penduduk Miskin yang Komprehensif dalam Rangka Perlindungan Penduduk Miskin di Kabupaten/Kota. SMERU. 2016

8. Tambunan, T. Perekonomian Indonesia. Ghalia Indonesia. Jakarta. 2003.

9. Ilmiawati, Y. Pengaruh Penerapan Model Mastery Learning Terhadap Hasil Belajar Siswa. Universitas Pendidikan Indonesia. 2014.

10. Abdullah, R. Faktor-Faktor Yang Mempengaruhi Ketimpangan Pendapatan di Jawa Tengah. Semarang. 2013.

11. BPS. Berita Resmi Statistik. 2007.

12. Ade, C. Bagaimana Kemiskinan Diukur. Govermance Brief. 2016.

13. Arius J. Analisis Pertumbuhan Ekonomi dan Kemiskinan di Indonesia. Jurnal Kajian Ekonomi. 2012.

14. Arsyad, L. Ekonomi Pembangunan. STIE YKPN. Yogyakarta. 2004.

15. Ayula C. Keterkaitan Pertumbuhan Ekonomi dan Pendapatan Perkapita Terhadap Kemiskinan Provinsi Jawa Tengah Tahun 2003-2010. 2012.

16. Olfie, B. Faktor-Faktor Yang mempengaruhi Ketimpangan Distribusi pendapatan di Sulawesi Utara. 2012.

17. Budiono, Prayudi S. Prabowo. Gambaran Umum Ketimpangan Pendapatan di Indonesia Dalam Persiapan Menuju Masyarakat Ekonomi ASEAN 2015. Surabaya. 2015

18. Candra M. Pengaruh PDB dan Jumlah 
Penduduk Terhadap Kemiskinan di Indonesia Periode 1990-2008. Jurnal Paradigma Ekonomika. 2011.

19. https://www.bi.go.id/id/ruang-media/siaranpers/Pages/sp_191017.aspx

20. https://www.indonesia-investments.com/ id/keuangan/angka-ekonomi-makro/ kemiskinan/item301?

21. Irfani, F. Perekonomian Indonesia Awal Tahun 2016. FEB. 2016

22. Isdijoso, W., Suryahadi, A., \& Akhmadi. Penetapan Kriteria dan Variabel Pendataan Penduduk Miskin yang Komprehensif dalam Rangka Perlindungan Penduduk Miskin di Kabupaten/Kota. The SMERU Research Institute. 2016.

23. Kuntoro. Metode Statistik. Surabaya: Pustaka Melati. 2007.

24. Ellah, N. Analisis Pengaruh Faktor-Faktor yang Berpengaruh Terhadap Kemiskinan di Jawa Timur, 2016. 1-9.

25. OECD. Survei Ekonomi OECD Indonesia. 2015.

26. Astuti, P. Aplikasi Analisis Kovarian (ANAKOVA) Pada Kasus Pengaruh Letak Daerah dan Jumlah Penduduk Miskin Terhadap Distribusi Pendapatan di Jawa Tenga. UNNES. 2009. 